\title{
STOCK MARKET REACTION TO ICT \\ IMPLEMENTATION: MODEL BASED \\ ON COMPARISON OF DEVELOPED \\ AND TRANSITION ECONOMIES
}

\author{
František Janke, Miroslava Packová, Mojmír Prídavok
}

\section{Introduction}

Nowadays, companies run their business in very competitive and ever changing environment trying to find the way to be more successful. According to the [1], [18] and [37], enterprises in both manufacturing and service sectors are more productive, grow faster, invest more, and are more profitable when using Information and Communication Technology (ICT) more intensively. The ICT sector contributes to technological progress, output and productivity growth ([28], [9]) even to a sustainable development [2]. As we are focusing on these benefits, it is not just about the companies that are getting more productive and growing, but as a consequence also economy as a whole can benefit from the better performance of companies that grow [27]. Exploiting the benefits of ICTs, both emerging and developed economies are focusing on innovation, competing globally for talent, resources, and market shares [3].

Since the first study [12], implementation of ICT has been shown as very important step for companies to increase their performance, many others have been published. Almost all researchers focused on developed economies as US, but in spite of a wide range of such studies, only few of them focused on transition/emerging economies [1], [11]. Interestingly, especially in these countries ICTs have been identified as an important key in shifting to a market driven economy [11]. Hence, mainly emerging and developing economies are seeking ways to improve productivity and find new sources of growth through new technologies [3].

The aim of this study is to provide a review of relevant studies in both, developed and transition/emerging economies. Through the comparison of two core studies [10], [11] that investigated stock market reaction to ICT investment announcements in four transition economies forming "Visegrad Group": Czech Republic, Hungary, Poland and Slovakia, and several studies that examined ICT's impact in developed economy - US, we provide an overview of different reactions of stock market to ICT investment announcements under different conditions. This is completed by the overview of the incidence of the influence of different factors, taking results for different samples from relevant past studies. Finally, a model, describing how the ICT investment influences stock price movements with respect to all significant factors provided by several studies in this area, will be provided.

\section{Literature Review}

Despite the fact, that many authors carried out research focused on impact of ICT on company's performance, there is a lack of studies focusing on investigation of the stock market reaction (resulting in stock price change) to ICT investment announcements. This is supported by poor results in terms of quantity for search attempts (realized in Oct/Nov 2013, used keywords: infomation-communication technology, information Technology (incl. abbreviations ICT or IT), investment, implementation, impact, stock market, stock price, reaction) in well-known research databases - e.g. Web of Science, Scopus, EBSCO, etc. The main studies have been conducted mainly in the developed countries, especially USA. However in transition countries very few studies have been carried out. In this chapter we provide a summary of literature in both, developed and transition economies since the first study investigating impact of ICT.

The very first study focused on ICT domain was conducted by [12], where market reaction to ICT investments in US companies has been investigated. They examined 97 ICT investments of US companies between 
1981 and 1988. For this sample no positive reaction has been identified. The same results have been shown also in the study by [21]. In the cross/sectional analysis, [12] divided the origin sample into two groups according to innovativeness of investments. Positive significant reaction only for innovative ICT has been found. The value of innovative ICT investments has been proven also by [20]. Other results were published in the study conducted by [15], where 232 ICT investment announcements in e-commerce by Australian companies from over a 13-years period have been investigated. Although they found positive reaction for a whole sample, cross-sectional analysis brought other results for innovative ICT as compared with [12]. Positive significant reaction was found only for non-innovative ICT investments. E-commerce applications have been analysed also by [23], [31].They found positive significant impact of e-commerce use on the market value of companies.

In 2005 the UK Office for National Statistics published a set of studies [5], showing that the effects of ICT investments depend on contingent factors, including whether the companies operate on a multinational level, whether they have a US home base, their age, and whether they are manufacturing or service providing companies. In [14] it is also claimed that ICT impact depends on the sector which companies operate. In the research conducted by [16], ICT impact in 13 EU countries has been studied. Strong relationship between ICT use and company performance in Nordic states, France, UK and Netherlands has been shown. When distinguishing companies by time, they came to the next results: in manufacturing firms, firm's productivity is very strong linked to intensity of e-procurement; in distribution service to intensity of use of e-commerce for selling. Also in UK ICT capital has a positive impact on productivity level, but in Netherland ICT capital was identified as insignificant.

Positive abnormal return can be seen also in the study by [21], especially in ICT infrastructure investments as compared to ICT applications investments. The fact that ICT implementation leads to an abnormal returns of companies confirmed also [4], [7], [27], [36] etc. [25] found positive abnormal excess for China companies, but on the other hand not for US ones. A little or no reaction to ICT announcements has been confirmed in [8].
The stock market reaction to 66 ICT investment announcements in Poland has been investigated in [11]. For a whole sample there was no evidence of significant reaction, however, after the sample was broken down by five groups of factors (see Figure 1), positive significant reaction was found when ICT was acquired from a global vendor, when announcement was released under conditions of a declining market and in a local language, and when announcement informed about completed ICT investment.

The investigation of three other "Visegrad" counties: Czech Republic, Hungary and Slovakia by [10] showed different results even if these countries are transition economies of Central Europe just as a Poland. Positive significant reaction has been found for a whole sample consisting of 95 announcements, the same result was found when company implementing ICT has beta factor higher than 0.9 . Significant negative reaction has been found when announcement was released under conditions of declining market. When comparing studies [10], [11] investigating transition economies and the other studies examining impact of ICT implementation in developed economies, it is obvious, that the ICT investment announcements under different conditions influence stock market in different ways related to the type of economy. In order to highlight the most important differences between reactions to ICT announcement under different conditions in these countries, we used an explanatory model explained by [29], the same model as the one in the above mentioned studies. This model including five categories of factors within an abnormal return of company under particular conditions was measured (Figure 1).

Based on this model the results of stock market reactions from US as a developed country [19], [30] and transition countries Czech Republic, Hungary, Slovakia [10] and Poland [11] were compared. However, in each of five categories there are more factors influencing the impact of ICT investment announcements. Based on the previous studies only one factor from almost each category allowing comparison among developed and emerging economies was found. For the categories - Announcement Characteristics and ICT Investment Type, no factor that would have enabled this comparison could have been found, as it was not possible 

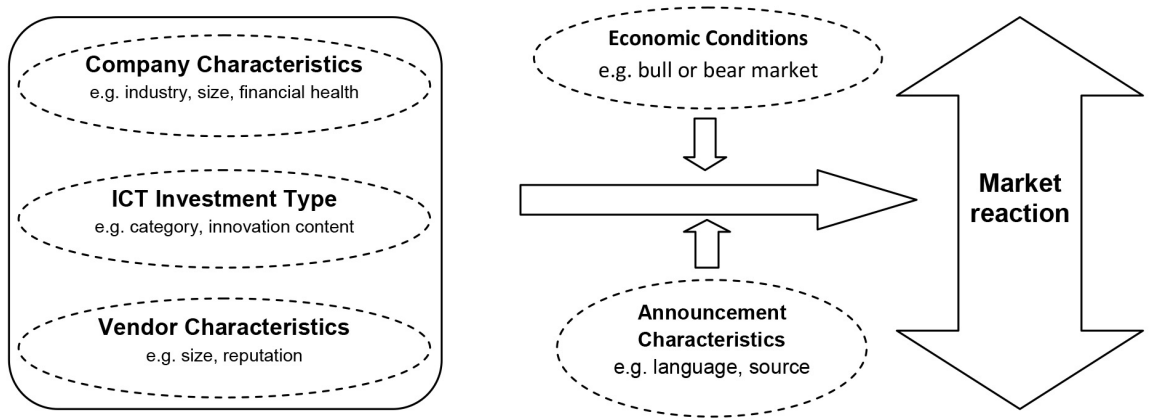

Source: [29]

to find two studies, one from emerging and the other one from developed country, which investigated the same factors of these two categories.

\section{Vendor characteristics}

\section{Vendor's size}

The size of a company has been shown as a significant factor for market reaction to ICT investment announcements; not only for companies publishing ICT implementation (e.g. [19]), but also for companies providing ICT solutions - vendors.

In developed countries such as US, the positive significant reaction for large global vendors has been found [19]. According to the [19], this effect is caused by higher quality of auditor companies, which is correlated with company's size. On the other hand, in transition economies positive reaction for global vendor has been found only in Poland. In Czech Republic, Hungary and Slovakia there was no evidence of significance for these types of vendors, but on the contrary, small local vendors use to affect stock market in a significant positive way [10], [11]. This difference may be caused by a size of economics of these countries, as compared to Poland and US.

\section{Company characteristics}

Beta value

Based on the Capital Asset Pricing Model (CAPM) beta value represents a systematic risk, which measures the sensitivity of stock's return to overall market movements [13]. Higher beta factor signifies higher gain potential. Based on this fact, there is an assumption that companies with higher beta factor react more positively to ICT investment announcements.

However, higher beta factor has shown negative significance for US companies [30], while in transition economies it has shown positive significant reaction - except for Poland - there was no significance found. A positive reaction means, that stock prices of the companies are moving in the same direction as a stock market and vice versa. Concerning the transition economies, the study by [22] confirmed positive reaction to the ICT investment announcements of those Czech companies that had been traded on a stock exchange for more than 10 years. On the other hand, negative reaction was found for Hungarian companies that had been traded for less than 10 years. It was not possible to compare this result with the result of developed economy, as there was no study that would investigated this factor on the US market. On the contrary, the other factors of this category that were found in the studies focused on the US market are for instance type of company's industry [21] or its size [19]

\section{Economic conditions}

Market conditions

Market conditions under which the announcements of ICT are released can influence the impact 
of these announcements. Depending on dominant conditions, two types of markets can be defined: a market of declining indexes - so called bear market and a market of increasing indexes - so called bull market. The impact of ICT investment announcements on the US market have been investigated under these different conditions [30]. They came to the conclusion that in the bear market where unfavourable conditions are dominant, the investors' reactions are negative. These results were supported also by the studies examining a market reaction in transition economies except for Poland [10], [11].

\section{Other factors}

There are many other factors influencing the impact of ICT on market reaction, as it has been confirmed in previous studies. However, these factors were examined in the studies focused on either transition economies or developed economies.

\section{ICT investment type}

The other factor of the explanatory model from the category ICT investment type is also status of ICT investment that was examined in the study by [10], [11]. Here the two types of investments are distinguished: completed and future projects. Completed project does not need the added financial funding, so investors can perceive a completed project more positively as compared to the planned ICT investments or projects in- progress. This assumption was confirmed in all "Visegrad" countries.

Also the particular type of ICT investment showed an effect on ICT's impact. There were many studies investigating effect of special types of investments, as for instance, in e-commerce [15], [31], in ERP [19], or in CRM, etc., however they were conducted only on the markets of developed economies.

Announcement characteristics

In the study by [11] also the impact of investment announcement's language (Polish) was confirmed. On the contrary, other studies did not support this finding [10], [21]. On the other hand, also the source releasing the announcement (the vendor or the company, where the ICT was implemented) was identified as important factor.

The other factor is an innovation content, where the differences between innovative and non-innovative ICT investments were identified in the results. Positive impact of innovative ICT investments has been proven in the US study by [12] and [20], but on the contrary positive impact of non-innovative investments has been proven as well [15].

To summarize the above mentioned studies examining the significance of different factors under which the ICT implementation has an impact on a stock market reaction, we provide Table 1, which contains information about how often were the particular factors influence

\section{Tab. 1: Summary on significance of 7 factors in 5 relevant studies}

\begin{tabular}{|c|c|c|c|c|c|c|c|c|}
\hline \multirow[b]{2}{*}{ Factor } & \multicolumn{3}{|c|}{$\begin{array}{c}\text { Janke and } \\
\text { Packova [22] }\end{array}$} & \multirow{2}{*}{$\begin{array}{c}\begin{array}{c}\text { Dobija } \\
\text { et al. } \\
\text { [11] }\end{array} \\
\text { PL }\end{array}$} & \multirow{2}{*}{$\begin{array}{c}\begin{array}{c}\text { Delina et } \\
\text { al. [10] }\end{array} \\
\text { V4 } \\
\text { countries }\end{array}$} & \multirow{2}{*}{$\begin{array}{c}\text { Hayes [19]; } \\
\text { Roztocki et } \\
\text { al. [30] }\end{array}$} & \multirow{2}{*}{$\begin{array}{c}\text { Confirmation } \\
\text { ratio }\end{array}$} & \multirow{2}{*}{ Ranking } \\
\hline & HU & CZ & SK & & & & & \\
\hline Vendor & - & $x$ & - & $x$ & - & $\mathrm{x}$ & $3 / 6$ & 4 \\
\hline $\begin{array}{l}\text { Company } \\
\text { characteristics }\end{array}$ & $\mathrm{x}$ & $\mathrm{x}$ & $\mathrm{x}$ & - & $\mathrm{x}$ & $x$ & $5 / 6$ & 1 \\
\hline Market conditions & $x$ & $x$ & - & - & $x$ & $x$ & $4 / 6$ & 2 \\
\hline Investment status & $x$ & $x$ & - & $\mathrm{x}$ & - & $\mathrm{N} / \mathrm{A}$ & $3 / 5$ & 3 \\
\hline $\begin{array}{l}\text { Announcement } \\
\text { characteristics }\end{array}$ & $x$ & $x$ & - & $\mathrm{x}$ & - & $\mathrm{N} / \mathrm{A}$ & $3 / 5$ & 3 \\
\hline Economic conditions & $x$ & $x$ & - & $\mathrm{N} / \mathrm{A}$ & N/A & $\mathrm{N} / \mathrm{A}$ & $2 / 3$ & 2 \\
\hline
\end{tabular}


confirmed - meaning the factor significance (significance at least at the level of $90 \%$ ) was present. Based on the the confirmation ratio of significance of given factors of 5 relevant studies showing the incidence of the influence of factor (Having in mind the methodology of the studies Hayes et al [19]; Roztocki and Weistroffer [30]; Dobija et al. [11]; Delina et al. [10]; Janke and Packova [22], we have to stress out that the ranking does not provide the information about the level of the factors' impact. It merely provides the information about the success rate of the corroboration of particular factors' impact.) was constructed.

As can be seen from the Table 1, from the analysed factors, the most of studies has examined the significance of vendors, company characteristics and market conditions. Relatively the highest confirmation ratio of significance has a factor "company characteristics". That means company characteristics were corroborated in almost every sample (exept of Poland), meaning this factor has to be considered as very important in the processes of ICT implementation's influence on stock market prices. Second place in the ranking belongs to market and economic conditions, when they were found as significant factors in 4 from 6 studies (market conditions) and 2 from 3 studies (economic conditions). On the other hand, the lowest confirmation ratio has been found for vendor characteristic.

\section{Model}

Based on the previous researches, a model describing factors that influence company's stock price movement after ICT solution implementation and announcement, has been proposed (Fig. 2).

In order to understand the process of a change in the stock prices of the companies triggered by ICT implementation, we start with first factor that influence other subsequent factors. Many studies confirmed the importance of company's type when examining impact of ICT [19], [21]. Type of a company underlies type of ICT that the company is about to implement. For example young company is not going to implement sophisticated ICT innovative solution, but starts building ICT infrastructure comprising of, for instance, hardware and software solutions. Different ICT solutions will be implemented in a manufacturing company as compare to a business or non-manufacturing company. Also the size of a company is an important factor, because a large company has enough resources to purchase more expensive solutions followed by vast innovation as compare to a small company.

Implementing some type of ICT solution in company related to company's characteristics is followed by publishing an announcement about this implementation. In some cases company can release an announcement related to an ICT solution, that is only about to be implemented.

\section{Fig. 2: Model}

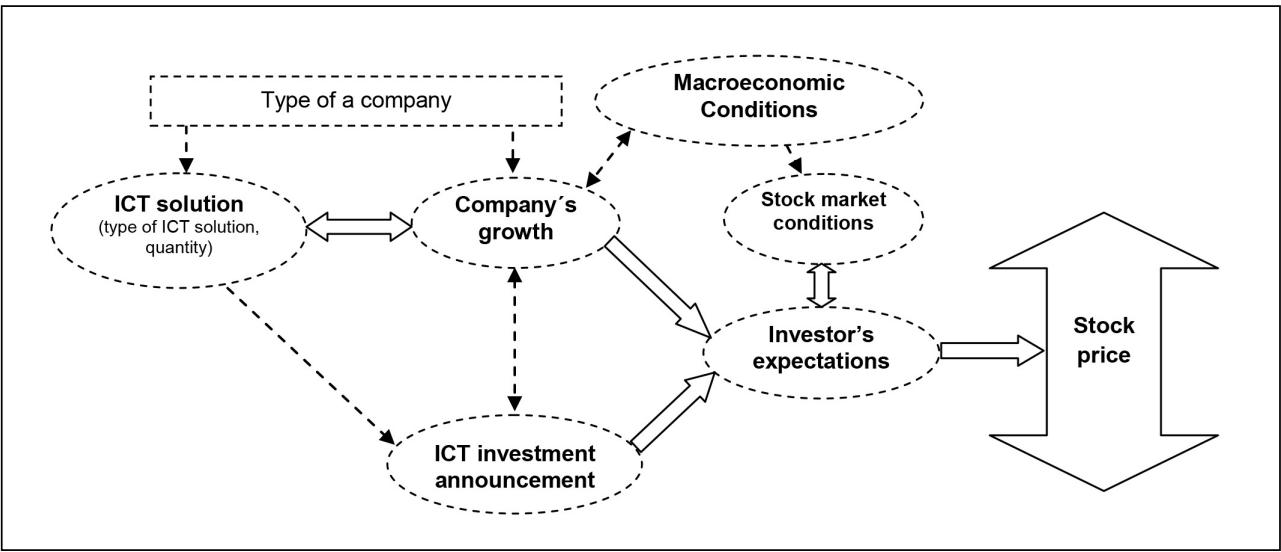


As it has been confirmed in some studies, mainly announcements of completed ICT projects lead to changes on a stock market [10], [11]. After releasing such an announcement, investors get positive information and perceive a company as one with the growth potential. Based on this information they buy shares of this company and that leads to the increase in the stock price of this company.

From the other point of view, good chosen and implemented ICT solution can lead to a better company performance and its growth [26], [9]. Company growth depends not only on internal factors (especially ICT implementation) but even on external factors such as macroeconomic ones (type of economy: developed/transition, economic cycle: expansion/recession, etc.). On the other hand, it works also a vice versa when implementation of ICT solution in a company leads not only to better performance of this company, but also to better performance of an economy as a whole [6], [28], [35]. When a company is doing well, has higher income, spends more money and that creates a spiral of money in the economy and that causes economy growth (expansion). From the point macroeconomic of macroeconomic view, the situation in economy influences ICT innovation activity at the company level. As it has been proven by [32], companies in recession invest less in new ICTs. On the other hand in expansion there is a higher ICT innovation activity.

As can be seen on a Figure 2, macroeconomic situation has also impact on market condition - mood on the market (bull and bear market) and finally expectations of investors that push stock prices up or down and vice versa. When summarizing the knowledge gained, stock prices of companies are in the context of ICT affected by the fact of ICT implementation and economic situation that underlies behaviour of investors on a capital market. This is in compliance with Drasnar's theory stating, that under a good market conditions - bull market investors are buying shares that lead to higher prices of shares and a vice versa [23]. Also in some studies [10], [11], [30] it has been confirmed that market conditions (bull, bear market) are an important factor of a market reaction.

This model respects the influence of most commonly discussed factors, however company's performance and their stock prices can be affected by many other external (e.g. rating changes [34]) or internal ones (e.g. internal planning [17]; [33] or business strategies [24]). These factors could be added with the aim to create more comprehensive model describing a flow of stock price's influencing factors related not only to ICT's use. Given model could be also extended by the determination the weight of its factors, which was not possible to achieve using the results of existing studies. Both goals, investigation of the flow of impact and the level of the impact of mentioned factors on the stock prices, would require the elaboration of very ofcomplex analysis which is very challenging task for future research.

\section{Conclusion}

ICTs play a crucial role in getting more competitive, profitable not only at a company level, but even at macroeconomic level. Companies implementing or using ICTs achieve better performance that affects their value in a positive way, for example through the increase of their stock prices where expectations of investors are crucial. However, according to [28], there is a difference among economies when comparing impact of ICT. In order to support this statement the review of some studies related to two economy types: developed (US) and emerging/transition country (Czech Republic, Hungary, Poland, Slovakia) has been provided. When analysing ICT impact on stock prices under some conditions (market conditions, company characteristics, vendor characteristics and other factors) in these two types of countries, the only factors causing, that stock market reacts on ICT investment announcement in the same direction, are market conditions. Other factors like vendors, company's characteristics etc., were either not significant or did not influence market reaction in the same way. We also provided a comparison aimed at significance incidence of mentioned factors investigated in 5 studies, with the aim to rank these factors according to the frequency of confirmation of their significance. Based on the studies available in this area we were also able to provide a model describing the flow of impact of ICT implementation on stock market reaction.

Our paper providing mainly literature overview and comparison of research results provides a base for future research focused on examining the impact of ICT where other results 
from both, developed and transition economy, can be added and compared.

This research was realized within national research project VEGA 1/1042/12 "Stock market reaction to IT investments: Evidence from the Visegrád Countries" financed by Ministry of Education, Science, Research and Sport of the Slovak Republic. We would also like to thank all reviewers for their valuable comments we received during the blind review process.

\section{References}

[1] ANTLOVÁ, K., POPELÍNSKÝ, L., TANDLER, J. Long Term Growth of SME from ICT Competencies and Web Presentations. E+M Ekonomie a Management. 2011, Vol. 14, Iss. 4, pp. 125-139. ISSN 1212-3609.

[2] BASL, J., DOUCEK, P. ICT and Innovations in Context of the Sustainable Development. In: DOUCEK, P., et al. (Eds.). IDIMT 2013: Information Technology, Human Values, Innovation and Economy: 21th Interdisciplinary Information Management Talks: Sept. ®11-13, ®2013 Prague, Czech Republic. Linz: Trauner, 2013. pp. 87-96. ISBN 978-3-99033-083-8.

[3] BILBAO-OSORIO, B., DUTTA, S., LANVIN, B. Global Information Technology Report 2013: Growth and Jobs in Hyperconnected World. Geneva: World Economic Formu and INSEAD, 2013. 409 s. ISBN 978-92-95044-77-7.

[4] BLOSE, L.E., SHIEH, J.C.P. Tobin's q-Ratio and Market Reaction to Capital Investment Announcements. The Financial Review. 1997, Vol. 32, Iss. 3, pp. 449-476. ISSN 1540-6288. DOI: 10.1111/j.1540-6288.1997.tb00434.x.

[5] CLAYTON, T., et al. IT investment, ICT use and UK firm Productivity. Office for National Statistics. London School of Economics, 2005. [6] COLECCHIA, A. and SCHREYER, P. ICT Investment and Economic Growth in the 1990s: Is the United States a Unique Case? A Comparative Study of Nine OECD Countries. Review of Economic Dynamics. 2002, Vol. 5, Iss. 2, pp. 408-442. ISSN 1094-2025. DOI: 10.1787/078325004705.

[7] DEHNING, B., RICHARDSON, V.J. and ZMUD, R.W. The Value Relevance of Announcements of Transformational Information Technology Investments. MIS Quarterly. 2003, Vol. 27, Iss. 4, pp. 637-656. ISSN 2162-9730.

[8] DEL BRIO, E.B., PEROTE, J., PINDADO, J. Measuring the Impact of Corporate Investment
Announcements on Share Prices: The Spanish Experience. Journal of Business Finance \& Accounting. 2003, Vol. 30, Iss. 5-6, pp. 715747. ISSN 1468-5957. DOI: 10.1111/14685957.05254.

[9] DELINA, R., TKAČ, M. The Impacts of Specific ICT Solutions on Productivity. In: IDIMT-2010: information technology human values, innovation and economy: 18th Interdisciplinary Information Management Talks: proceedings: September 8-10, 2010, Jindřichưv Hradec, Czech Republic. Linz: Trauner, 2010. pp. 23-32. ISBN 978-3-85499-760-3.

[10] DELINA, R., PACKOVÁ, M., ROZTOCKI, $N$. and WEISTROFFER, H.R. Information Technology Investments and Stock Market Reaction: Evidence from Czech Republic, Hungary and Slovakia. In: Proceedings of the Second International Conference on ICT (ICTM 2013). Wroclaw, Poland. 2013, pp. 98-105. ISBN 978-83-64-389-00-9.

[11] DOBIJA, D., KLIMCZAK, K.M., ROZTOCKI, N. and WEISTROFFER, H.R. Information technology investment announcements and market value in transition economies: Evidence from Warsaw Stock Exchange. The Journal of Strategic Information Systems. 2012, Vol. 21, Iss. 4, pp. 308-319. ISSN 0963-8687. DOI: 10.1016/j.jsis.2012.07.003.

[12] DOS SANTOS, B.L., PEFFERS, K., MAUER, D. The impact of information technology investment announcements on the market value of the firm. Information Systems Research. 1993, Vol. 4, Iss. 1, pp. 1-23. ISSN 1047-7047. DOI: 10.1287/isre.4.1.1.

[13] FAMA, E.F., FRENCH, K.R. The Capital Asset Pricing Model: Theory and Evidence. Journal of Economic Perspectives. 2004, Vol. 18, Iss. 3, pp. 25-46. ISSN 0895-3309. DOI: 10.2139/ssrn.440920.

[14] FAROOQUI, S., SADUN, R. Broadband Availability, Use and Impact on Returns to ICT in UK firms. OECD Paper DSTI/ICCP/IIS, 2006. No. 9.

[15] FERGUSON, C., FINN, F., HALL, J. Electronic commerce investments, the resourcebased view of the firm, and firm market value. International Journal of Accounting Information Systems. 2005, Vol. 6, Iss. 1, pp. 5-29. ISSN 1467-0895. DOI: 10.1016/j.accinf.2004.08.001. [16] FRANKLIN, M., STAM, P., CLAYTON, T. ICT impact assessment by linking data across sources and countries. Sumarry report. Office for National Statistics, UK, 2008. 32 p. 
[17] GAVUROVÁ, B. Source Identification of Potential Malfunction of Balanced Scorecard System and Its Influence on System Function. E+M Ekonomie a Management. 2012, Vol. 15, Iss. 3, pp. 76-90. ISSN 1212-3609.

[18] GAVUROVÁ, B., ŠOLTÉS, M., BALLONI, A.J. Ekonomický význam využívania informačno-komunikačných technológií v systéme zdravotníctva. Ekonomický časopis. 2014, Vol. 62, Iss. 1, pp. 83-104. ISSN 00133035.

[19] HAYES, D.C., HUNTON, J.E. and RECK, J.L. Market Reaction to ERP Implementation Announcements. Journal of Information Systems. 2001, Vol. 15, Iss. 1, pp. 3-18. ISSN 0888-7985. DOI: 10.2308/jis.2001.15.1.3.

[20] CHANEY, P.K., DEVINNEY, T.M., WINER, R.S. The impact of new product introductions on the market value of firms. Journal of Business. 1991, Vol. 64, Iss. 4, pp. 573-610. ISSN 00219398. DOI: 10.1016/0167-6687(93)91065-3.

[21] CHATTERJEE, D., PACINI, C. and SAMBAMURTHY, V. The Shareholder-Wealth and Trading-Volume Effects of InformationTechnology Infrastructure Investments. Journal of Management Information Systems. 2002, Vol. 19, Iss. 2, pp. 7-42. ISSN 0742-1222.

[22] JANKE, F., PACKOVA, M. Impact of ICT Investments on Performance of Companies in Transition Economies: Evidence from Czech Republic, Hungary and Slovakia. Quality, Innovation, Prosperity. 2013, Vol. 17, Iss. 2, pp. 9-21. ISSN 1335-1745.

[23] LANG, L.H.P., STULZ, R.M., WALKLING, R.A. Managerial Performance, Tobin's $Q$, and the Gains from the Successful Tender Offers. Journal of Financial Economics. 1989, Vol. 24, Iss. 1, pp. 137-154. ISSN 0304 405X. DOI: 10.1016/0304-405x(89)90075-5.

[24] JOHANSON, B., SUDZINA, F., PUCIHAR, A. Impact of Business And Information Strategies Alignment On Business Performance. The 4th Mediterranean Conference on Information Systems, (MCIS 2009). Athens, Greece. 2009. pp 89. ISBN 978-960-98566-7-6.

[25] MENG, Z., LEE, S.-Y.T. The value of IT to firms in a developing country in the catch-up process: an empirical comparison of China and the United States. Decision Support Systems. 2007, Vol. 43, Iss. 3, pp. 737-745. ISSN 01679236. DOI: 10.1016/j.dss.2006.12.007.

[26] OECD. Economic, Environmental and Social Statistics. France: OECD Publication Service, 2013. ISSN 1995-3879.
[27] $\mathrm{OH}$, W., KIM, J.W. The Effects of Firm Characteristics on Investor Reaction to IT Investment Announcements. In: TwentySecond International Conference on Information Systems, Louisiana, USA. 2001, pp.145-156. ISBN 9781615670192.

[28] PILAT, D. ICT and Economic Growth: Evidence from OECD Countries, Industries and Firms. France: OECD Publication Service, 2003. ISBN 9264101284.

[29] ROZTOCKI, N. and WEISTROFFER, H.R. Stock Market Reaction to Information Technology Investments: Towards an Explanatory Model. In: 17th European Conference on Information Systems (ECIS 2009). Seoul, Korea. 2009. ISBN 978-1-60558-710-3.

[30] ROZTOCKI, N. and WEISTROFFER, H. R. How Do Investments in Enterprise Application Integration Drive Stock Prices? In: Proceedings of the 40th Hawaii International Conference on System Sciences (HICSS 2007), Hawai. 2007. ISBN 0-7695-2755-8. DOI: 10.1109/ hicss.2007.247.

[31] SUBRAMANI, M., WALDEN, E. The impact of electronic commerce announcements on the market value of firms. Information System Research. 2001, Vol. 12, Iss. 2, pp. 135-154. ISSN 1047-7047. DOI: 10.2139/ssrn.269668.

[32] SZABO, Z.K., ŠOLTÉS, M., HERMAN, E. Innovative Capacity \& Performance of Transition Economies: Comparative Study at the Level of Enterprises. E+M Ekonomie a Management. 2013, Vol. 16, Iss. 1, pp. 52-68. ISSN 1212-3609.

[33] ŠOLTÉS, V., GAVUROVÁ, B. The Functionality Comparison of the Health Care Systems by the Analytical Hierarchy Process Method. E+M Ekonomie a Management. 2014, Vol. 17, Iss. 3, pp. 100-118. ISSN 1212-3609. DOI: dx.doi.org/10.15240/tul/001/2014-3-009.

[34] UŽíK, M., ŠOLTÉS, V. The Effect of Rating Changes on the Value of a Company Listed in the Capital Market. E+M Ekonomie a Management. 2009, Vol. 12, Iss. 1, pp. 49-55. ISSN 1212-3609.

[35] VU, K. Measuring the Impact of ICT Investments on Economic Growth [online]. Cambridge (MA): Harvard Kennedy School of Government [cit. 2014-10-10]. Working paper. 41 p. (PDF). Available from: http://www.hks. harvard.edu/m-rcbg/ptep/khuongvu/Key\%20 paper.pdf.

[36] WOOLRIDGE, J.R., SNOW, C. Stock Market Reaction to Strategic Investment 
Decisions. Strategic Management Journal. 1990, Vol. 11, Iss. 5, pp. 353-363. ISSN 10970266. DOI: $10.1002 / \mathrm{smj} .4250110503$.

[37] WORLD BANK. Information \& Communication Technologies. Sector Strategy [online]. Washington: World Bank, c2001 [cit. 2014-04-17]. 29 p. (PDF). Available from: http://siteresources.worldbank.org/ INTICTSTRATEGY/Resources/2010-11-23_ ICT_Sector_Strategy_Approach_Paper.pdf.
Ing. František Janke, PhD.

Technical University of Košice

Faculty of Economics

Department of Banking and Investment frantisek.janke@tuke.sk

Ing. Miroslava Packová

Technical University of Košice

Faculty of Economics

Department of Banking and Investment miroslava.packova@tuke.sk

Ing. Mojmír Prídavok, PhD. Technical University of Košice Faculty of Economics Department of Banking and Investment mojmir.pridavok@tuke.sk 


\section{Abstract}

\section{STOCK MARKET REACTIONTO ICT IMPLEMENTATION: MODEL BASED ON COMPARISON OF DEVELOPED ANDTRANSITION ECONOMIES}

\section{František Janke, Miroslava Packová, Mojmír Prídavok}

Companies are more productive, grow faster, invest more, and are more profitable when using Information and Communication Technology (ICT) more intensively. Several studies provided evidence that implementation of ICT into companies' processes contributes to economic growth both on companies' and macroeconomic level. In spite of wide range of studies in this area, only few studies focused on how the ICT implementation is perceived by investors at stock market and whether this information make movements in companies' shares prices. Hence, the purpose of this paper is to provide literature overview related to the area of the impact of ICT implementation on company's stock price, comparing results from developed (US) and transition economies (Czech Republic, Hungary, Poland and Slovakia) and using the results from relevant literature to provide a comparison of incidence of particular factors' influence on the impact of ICT implementation on company's stock prices. Based on the previous researches, a model describing factors that influence company's stock price movement after ICT solution implementation and announcement, has been created.

Key Words: Information-Communication Technology, market reaction, stock price.

JEL Classification: L19, O33, O43.

DOI: 10.15240/tul/001/2015-3-009 